\title{
PENINGKATAN EFEKTIVITAS PEMBELAJARAN LARUTAN PENYANGGA MELALUI PENDEKATAN SAVI (Somatis, Auditori, Visual, dan Intelektual) PADA SISWA KELAS XI SMAN 21 JAKARTA
}

Arieztania Rahmadhani, Irma Ratna Kartika, dan Muktiningsih* Jurusan Kimia, Fakultas Matematika dan Ilmu Pengetahuan Alam, Universitas Negeri Jakarta, Jl. Pemuda 10 Rawamangun, Jakarta. Indonesia.

*Corresponding Author: mutinurjayadi@yahoo.com

\begin{abstract}
Abstrak
Penelitian ini bertujuan untuk meningkatkan efektivitas pembelajaran larutan penyangga melalui pendekatan SAVI (Somatis, Auditori, Visual, dan Intelektual) dengan menggunakan panduan dan CD praktikum pada siswa kelas XI SMAN 21 Jakarta. Penelitian ini dilakukan mulai Desember 2011 hingga April 2012. Untuk dapat meningkatkan efektivitas pembelajaran Larutan Penyangga melalui pendekatan SAVI, terlebih dahulu perlu diketahui gaya belajar dominan siswa dan karakteristik materi yang diajarkan. Setelah itu, guru dapat menentukan metode dan media pembelajaran yang sesuai dengan karakteristik materi dan gaya belajar dominan siswa. Penggunaan panduan dan CD praktikum sebagai implementasi dari pendekatan SAVI dapat mengoptimalkan gaya belajar visual dan auditori siswa. Selain itu, kegiatan praktikum di laboratorium yang sesuai dengan karakteristik materi Larutan Penyangga dapat mengoptimalkan gaya belajar somatis siswa.Metode penelitian yang digunakan yaitu penelitian tindakan kelas (classroom action research) yang dilakukan selama dua siklus. Penelitian ini dimulai dengan analisis pendahuluan berupa wawancara guru dan angket siswa untuk memperoleh data acuan perencanaan tindakan. Hasil penelitian menunjukkan bahwa efektivitas pembelajaran Larutan Penyangga mengalami peningkatan dari siklus I ke siklus II. Salah satu indikatornya adalah kualitas hasil belajar siswa, yaitu meningkatnya rata-rata hasil belajar siswa dari 73,89 pada siklus I menjadi 81,28 pada siklus II.
\end{abstract}

Kata kunci : efektivitas, pendekatan SAVI, larutan penyangga

\begin{abstract}
The purpose of this research was to increase learning effectiveness of buffer solution through SAVI (Somatic, Auditory, Visual, and Intellectual) approach using experiment guide and CD in class XI SMAN 21 Jakarta. It started from December 2011 until April 2012. The method was classroom action research in two rounds. This research started with preliminary analysis by teacher interview and student questionnaire to make the lesson plan. The results showed that the learning effectiveness had enhancement from first cycle to second cycle. It could be seen from the average of learning outcomes that increased from 73,89 in first round to 81,28 in second round. To increase learning effectiveness of buffer solution through SAVI approach, first we could know the dominant learning style of student in that class and the characteristic of subject that learnt. After that, teacher could determine learning method and media that suited with them. Application of experiment guide and $C D$ as implememtation of SAVI approach could optimized visual and auditory learning style of student. Besides that, experiment in the laboratory could optimized somatic learning style of student.
\end{abstract}

Keywords : effectiveness, SAVI approach, buffer solution

\section{Pendahuluan}

Peningkatan kualitas sumber daya manusia dipengaruhi oleh kualitas pendidikan. Dalam upaya peningkatan kualitas pendidikan, pemerintah mulai mengembangkan SMA yang berpotensi untuk melaksanakan proses layanan pendidikan yang berkualitas dan menghasilkan lulusan yang diakui secara nasional maupun internasional, yaitu melalui Rintisan SMA Bertaraf Internasional (RSMA-
BI). Hal tersebut sesuai dengan UndangUndang Nomor 20 tahun 2003 tentang Sistem Pendidikan Nasional pasal 50 ayat 3 yang menyebutkan bahwa pemerintah dan/atau pemerintah daerah menyelenggarakan sekurang-kurangnya satu satuan pendidikan pada semua jenjang pendidikan untuk dikembangkan menjadi satuan pendidikan bertaraf internasional [1]. 
Rintisan SMA Bertaraf Internasional pada umumnya menerapkan kurikulum nasional yaitu Kurikulum Tingkat Satuan Pendidikan (KTSP) 2006 yang diperkaya dengan kurikulum internasional seperti kurikulum Cambridge. Proses pembelajaran di RSMA-BI berlangsung secara bilingual atau menggunakan dua bahasa, yaitu bahasa Indonesia dan bahasa Inggris. Selain itu, pelaksanaan proses pembelajarannya juga didukung dengan penggunaan media berbasis Information and Communication Technology (ICT) [2].

Kualitas hasil belajar, selain dipengaruhi oleh kemampuan intelektual siswa, juga dipengaruhi oleh gaya belajar masing-masing siswa. Gaya belajar yang dimaksud antara lain, gaya belajar visual, auditori, dan kinestetik. Masing-masing gaya belajar tersebut memiliki karakteristik yang berbeda-beda. Gaya belajar visual menitikberatkan pada penglihatan (visual), sedangkan auditori mengandalkan pendengaran (audio) untuk memahami dan mengingat. Berbeda dengan keduanya, gaya belajar kinestetik mengharuskan individu yang bersangkutan untuk menyentuh sesuatu yang bisa memberikan informasi tertentu agar bisa mengingatnya. Dalam proses pembelajaran, dibutuhkan suatu pendekatan yang dapat mengakomodasi semua gaya belajar tersebut, yaitu melalui pendekatan SAVI (Somatis, Auditori, Visual, dan Intelektual) [3].

Dalam KTSP 2006, materi larutan penyangga diberikan pada siswa kelas XI SMA pada semester 2. Berdasarkan kurikulum tersebut, materi larutan penyangga meliputi sifat larutan penyangga, penentuan $\mathrm{pH}$ larutan penyangga, serta fungsi larutan penyangga. Pada kurikulum Cambridge ( $A$ \& AS Level), larutan penyangga (Buffer Solution) termasuk kedalam kesetimbangan ion. Dalam kurikulum tersebut, hal-hal yang dipelajari pada materi larutan penyangga antara lain konsep larutan penyangga dapat mempertahankan $\mathrm{pH}$, fungsi dan aplikasi larutan penyangga, serta penentuan $\mathrm{pH}$ larutan penyangga.
Pada materi larutan penyangga, kegiatan praktikum di laboratorium sangat penting dilakukan oleh siswa untuk memperkuat atau meningkatkan pemahaman siswa mengenai materi larutan penyangga yang diperoleh di kelas. Minimnya kegiatan praktikum di SMA umumnya disebabkan oleh kurang lengkapnya fasilitas laboratorium, waktu yang terbatas, serta kurangnya panduan praktikum. Oleh karena itu, dibutuhkan suatu media pembelajaran yang dapat memvisualisasikan materi yang diajarkan sehingga siswa dapat memahami materi tersebut dengan lebih baik.

Sebagai implementasi dari pendekatan SAVI, digunakan suatu panduan dan CD praktikum untuk SMA kelas XI yang telah dikembangkan oleh Epik Mutiara (2011) [5]. Panduan dan CD praktikum tersebut untuk memudahkan siswa dalam melakukan praktikum larutan penyangga. Dari hasil analisis pendahuluan siswa SMAN 21 Jakarta yang dilaksanakan pada Desember 2011 diketahui bahwa lebih dari $60 \%$ siswa mengaku menyukai belajar kimia dengan menggunakan $C D$ pembelajaran terutama yang dilengkapi dengan animasi-animasi. Menurut para siswa, penggunaan $C D$ pembelajaran sedikitnya dapat memudahkan dalam memahami materi kimia bilingual. Panduan praktikum tersebut mendukung proses pembelajaran yang terpusat kepada siswa. Oleh karena itu, perlu dilakukan penelitian lebih lanjut untuk mengetahui efektivitas pembelajaran larutan penyangga dengan menggunakan panduan praktikum pada siswa SMA kelas XI.

\section{Metodologi Penelitian}

Penelitian ini dilaksanakan di SMA Negeri 21 Jakarta pada kelas XI semester genap tahun ajaran 2011/2012 mulai Desember 2011 hingga April 2012. Subjek penelitian ini adalah siswa kelas XI IPA 3 SMA Negeri 21 Jakarta di semester genap tahun ajaran 2011/2012. Metode yang digunakan pada penelitian ini 
Tabel 1. Perbandingan Hasil Pencapaian Indikator Efektivitas Pembelajaran Larutan Penyangga pada Siklus I dan II.

\begin{tabular}{|c|c|c|c|c|c|}
\hline \multirow[b]{2}{*}{ Indikator } & \multirow[b]{2}{*}{ Aspek Penilaian } & \multicolumn{2}{|c|}{ Siklus I } & \multicolumn{2}{|c|}{ Siklus II } \\
\hline & & $\begin{array}{l}\text { Lembar } \\
\text { Observasi }\end{array}$ & $\begin{array}{l}\text { Angket } \\
\text { Siswa }\end{array}$ & $\begin{array}{l}\text { Lembar } \\
\text { Observasi }\end{array}$ & $\begin{array}{l}\text { Angket } \\
\text { Siswa }\end{array}$ \\
\hline \multirow{3}{*}{$\begin{array}{l}\text { Keterlaksanaan } \\
\text { program } \\
\text { pembelajaran oleh } \\
\text { siswa }\end{array}$} & $\begin{array}{l}\text { Siswa memahami petunjuk guru } \\
\text { dengan benar }\end{array}$ & $97,50 \%$ & $97 \%$ & $100 \%$ & $97 \%$ \\
\hline & Siswa turut serta dalam pembelajaran & $72,50 \%$ & $64 \%$ & $82,80 \%$ & $85 \%$ \\
\hline & $\begin{array}{l}\text { Pemanfaatan sumber belajar yang } \\
\text { disediakan }\end{array}$ & $47,15 \%$ & $63,50 \%$ & $47,15 \%$ & $82,33 \%$ \\
\hline \multirow{2}{*}{$\begin{array}{l}\text { Keaktifan siswa } \\
\text { dalam proses } \\
\text { pembelajaran }\end{array}$} & $\begin{array}{l}\text { Siswa bertanya bila tidak memahami } \\
\text { materi pelajaran }\end{array}$ & $31,30 \%$ & $86,50 \%$ & $51,40 \%$ & $89,50 \%$ \\
\hline & $\begin{array}{l}\text { Siswa terlibat dalam pemecahan } \\
\text { masalah }\end{array}$ & $48,60 \%$ & $77,50 \%$ & $69,30 \%$ & $83,50 \%$ \\
\hline \multirow{3}{*}{$\begin{array}{l}\text { Interaksi guru } \\
\text { dengan siswa dan } \\
\text { siswa dengan } \\
\text { siswa }\end{array}$} & $\begin{array}{l}\text { Tanya jawab antara guru dengan } \\
\text { siswa }\end{array}$ & $100 \%$ & $88 \%$ & $100 \%$ & $91 \%$ \\
\hline & Tanya jawab antar siswa & $100 \%$ & - & $100 \%$ & - \\
\hline & Guru sebagai fasilitator & $100 \%$ & $94 \%$ & $100 \%$ & $97 \%$ \\
\hline \multirow{3}{*}{$\begin{array}{l}\text { Kemampuan dan } \\
\text { keterampilan guru }\end{array}$} & Guru menguasai materi pelajaran & $100 \%$ & $97 \%$ & $100 \%$ & $100 \%$ \\
\hline & $\begin{array}{l}\text { Guru terampil menggunakan media } \\
\text { pembelajaran }\end{array}$ & $100 \%$ & $91 \%$ & $100 \%$ & $98 \%$ \\
\hline & Guru mengendalikan kegiatan siswa & $100 \%$ & - & $100 \%$ & - \\
\hline \multirow{2}{*}{$\begin{array}{l}\text { Kualitas hasil } \\
\text { belajar siswa }\end{array}$} & Rerata nilai tes akhir siklus & 73,89 & - & 81,28 & - \\
\hline & $\begin{array}{l}\text { Jumlah siswa yang mencapai Kriteria } \\
\text { Ketuntasan Minimal (75) }\end{array}$ & 20 & - & 27 & - \\
\hline
\end{tabular}

adalah Penelitian Tindakan Kelas (PTK) yang terdiri dari empat tahap yaitu: (1) perencanaan (planning), (2) tindakan/pelaksanaan (acting), (3) pengamatan (observing), dan (4) refleksi (reflecting) [4].

Penelitian ini difokuskan pada peningkatan efektivitas pembelajaran Larutan Penyangga melalui pendekatan SAVI menggunakan panduan dan CD praktikum pada siswa kelas XI SMA Negeri 21 Jakarta. Indikator yang digunakan adalah keterlaksanaan program pembelajaran oleh siswa, keaktifan siswa dalam proses pembelajaran, kemampuan dan keterampilan guru, Interaksi guru dengan siswa dan siswa dengan siswa, dan kualitas hasil belajar siswa.
Penelitian ini diamati melalui lembar observasi, catatan lapangan, tes hasil belajar siswa pada akhir siklus, angket siswa pada akhir siklus. Instrumen yang digunakan adalah lembar wawancara guru, angket analisis pendahuluan untuk siswa, catatan lapangan, tes hasil belajar siswa pada akhir siklus, angket siswa pada akhir siklus. Alat pendukung yang digunakan pada penelitian ini adalah panduan dan CD praktikum materi Larutan Penyangga.

\section{Hasil Penelitian}

\section{Analisis Pendahuluan}

Dari hasil wawancara dengan guru kimia di SMA Negeri 21, diketahui bahwa pelaksanaan pembelajaran kimia, khususnya materi Larutan Penyangga, telah sesuai dengan kurikulum 


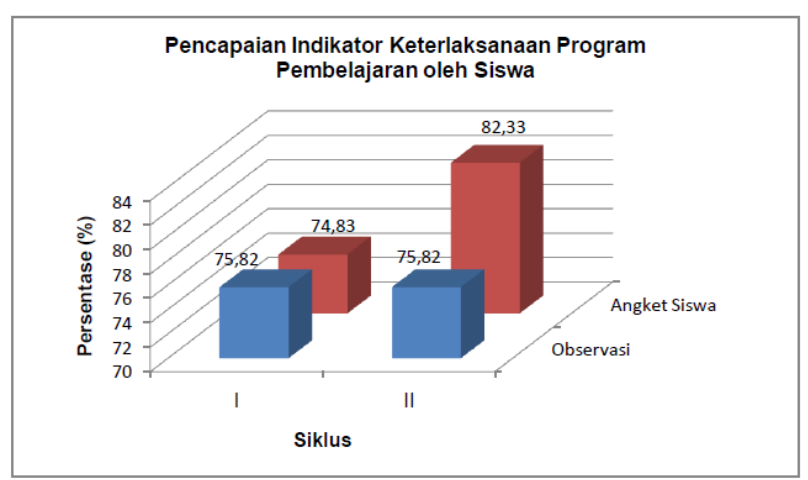

Gambar 1. Grafik Pencapaian Indikator Keterlaksanaan Program Pembelajaran oleh Siswa padaSiklus I dan II dari Hasil Observasi dan Angket Siswa. Dari hasil observasi (biru), pencapaian indikator keterlaksanaan program pembelajaran oleh siswa pada siklus I dan II adalah 75,82\%. Dari hasil angket siswa (merah), pencapaian indikator keterlaksanaan program pembelajaran oleh siswa mengalami peningkatan yaitu dari $74,83 \%$ pada siklus I menjadi $82,33 \%$ pada siklus II

yang digunakan, yaitu KTSP dan Cambridge. Metode pembelajaran yang biasa digunakan adalah diskusi informasi dan eksperimen di laboratorium. Metode eksperimen digunakan karena karakteristik materi Larutan Penyangga membutuhkan pengetahuan prosedural untuk menganalisis larutan yang bersifat penyangga dan bukan penyangga melalui percobaan.

Menurut beberapa guru, keaktifan siswa dalam proses pembelajaran umumnya masih kurang. Jumlah siswa yang aktif dalam diskusi, baik kelompok maupun kelas, hanya sekitar $20 \%$. Namun, sebagian besar siswa sudah mau bertanya kepada guru apabila ada hal-hal yang belum dipahami pada proses pembelajaran. Meskipun keaktifan siswa masih kurang, hasil belajar siswa sudah cukup baik. Pada materi Larutan Penyangga, kira-kira lebih dari $70 \%$ siswa tuntas atau telah mencapai Kriteria Ketuntasan Minimal (KKM). Pada pelaksanaannya, belum banyak guru yang menggunakan media pembelajaran berbasis ICT dengan alasan sering terjadi masalah teknis sehingga hanya akan menghabiskan waktu di kelas.
Dari hasil angket gaya belajar siswa, diketahui bahwa sebanyak $27,27 \%$ siswa memiliki gaya belajar dominan visual; $30,30 \%$ siswa memiliki gaya belajar dominan kinestetik (somatis); dan $42,42 \%$ siswa memiliki gaya belajar dominan auditori. Hal ini mengindikasikan bahwa siswa kelas XI IPA 3 memiliki beragam gaya belajar. Untuk mengatasinya, pada proses pembelajaran digunakan pendekatan SAVI (Somatis, Auditori, Visual, dan Intelektual).

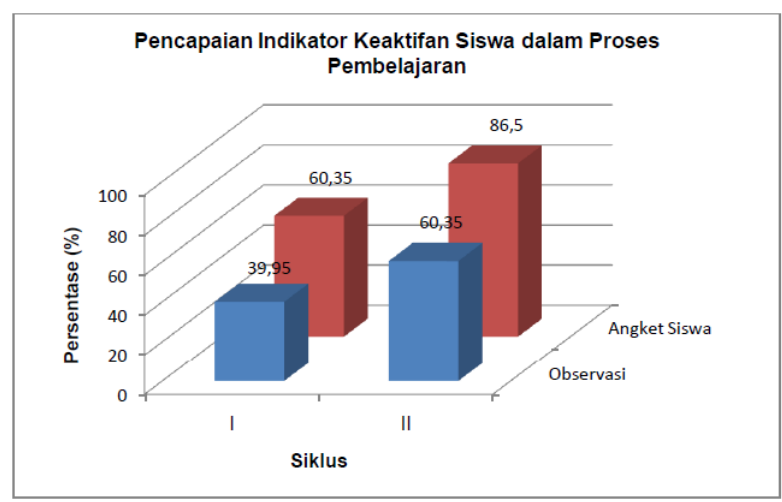

Gambar 2. Grafik Pencapaian Indikator Keaktifan Siswa dalam Proses Pembelajaran pada Siklus Idan II dari Hasil Observasi dan Angket Siswa. Dari hasil observasi (biru), indikator keaktifan siswa dalam proses pembelajaran meningkat dari 39,95\% pada siklus I menjadi 60,35\% pada siklus II. Dari hasil angket siswa (merah), indikator keaktifan dalam proses pembelajaran meningkat dari $60,35 \%$ pada siklus I menjadi $86,50 \%$ pada siklus II.

\section{Siklus I}

Siklus I terdiri dari empat pertemuan. Pada pertemuan pertama dilakukan pembelajaran Larutan Penyangga melalui kegiatan praktikum di laboratorium menggunakan panduan dan CD praktikum. Pertemuan kedua adalah pendalaman konsep Larutan Penyangga yang telah diperoleh siswa dari praktikum pada pertemuan pertama. Pada pertemuan ketiga, siswa mencoba menyelesaikan permasalahan mengenai Larutan Penyangga yang diberikan oleh guru. Setelah itu, dilakukan tes tertulis pada pertemuan keempat. 
Pada pertemuan pertama, proses pembelajaran dimulai di kelas dengan mengingatkan kembali siswa tentang materi sebelumnya, yaitu asam dan basa. Hal ini karena untuk mempelajari materi larutan penyangga, siswa membutuhkan pengetahuan dasar mengenai larutan asam dan basa. Apabila ditinjau dari definisinya, larutan penyangga merupakan larutan yang terdiri dari asam/basa dengan basa/asam konjugasinya. Ketika guru mengajukan pertanyaan mengenai asam dan basa, sebanyak 5 dari total 35 siswa langsung mengacungkan tangan untuk menjawab. Hal ini mengindikasikan bahwa keaktifan siswa sudah cukup baik.

Setelah itu, guru menjelaskan tujuan pembelajaran dan hubungan antara materi asam dan basa dengan larutan penyangga. Kemudian, guru membagikan LKS praktikum kepada masing-masing siswa dan menayangkan video praktikum yang akan dilakukan. Siswa mengamati dan menyimak dengan baik untuk mendapatkan sedikit gambaran mengenai praktikum yang akan mereka lakukan.

Sebelum ke laboratorium, guru membagi siswa menjadi delapan kelompok yang terdiri dari 4-5 orang. Pembagian kelompok tersebut didasarkan pada kemampuan intelektual dan keaktifan siswa. Siswa yang aktif, memiliki kemampuan intelektual sangat baik, dan siswa yang memiliki keduanya disebar kedalam masing-masing kelompok. Dengan pembagian kelompok tersebut diharapkan siswa yang aktif dapat membantu temannya yang kurang aktif dan siswa yang pandai dapat membantu temannya yang kurang pandai.

Siswa melakukan kegiatan praktikum di laboratorium sesuai dengan instruksi guru. Namun, saat praktikum, kondisi kelas kurang terkendali. Hal ini disebabkan antusiasme siswa terlihat sangat tinggi. Hasil praktikum yang dilakukan ditulis oleh masing-masing siswa pada lembar data pengamatan yang telah disediakan dan dipresentasikan di depan kelas.

Pada pertemuan kedua, hasil praktikum sebelumnya didiskusikan oleh guru dengan para siswa. Kemudian, guru membahas tentang komponen larutan penyangga, cara kerja larutan penyangga, dan cara menghitung $\mathrm{pH}$ larutan penyangga. Selanjutnya, guru memberikan latihan soal kepada siswa untuk dikerjakan. Soal yang belum selesai dikerjakan di rumah dan dibahas pada pertemuan ketiga. Pada pertemuan keempat, dilakukan tes akhir siklus I. Secara umum, hasil pengamatan indikator-indikator efektivitas adalah sebagai berikut :

a. Keterlaksanaan Program Pembelajaran oleh Siswa

Indikator keterlaksanaan program pembelajaran oleh siswa dilihat dari beberapa sub indikator diantaranya siswa memahami petunjuk guru dengan benar, siswa turut serta dalam pembelajaran, dan siswa memanfaatkan sumber belajar yang disediakan (text book dan LKS praktikum). Untuk indikator keterlaksanaan program pembelajaran oleh siswa pada siklus I ini, terdapat satu sub-indikator yang belum terpenuhi, yaitu pemanfaatan sumber belajar yang disediakan berupa text book (buku pelajaran) dan LKS praktikum. Dari lembar observasi maupun angket siswa, diketahui bahwa siswa belum memanfaatkan sumber belajar secara maksimal $(47,15 \%)$. Hal ini juga didukung dari catatan lapangan yaitu hampir seluruh siswa tidak membawa buku pelajaran kimia ketika proses pembelajaran berlangsung. Namun, secara keseluruhan indikator keterlaksanaan program pembelajaran oleh siswa telah tercapai dengan baik (>70\%).

b. Keaktifan siswa dalam proses pembelajaran Indikator keaktifan siswa dalam proses pembelajaran meliputi beberapa sub- 
Pencapaian Indikator Interaksi Guru dengan Siswa dan Siswa dengan Siswa

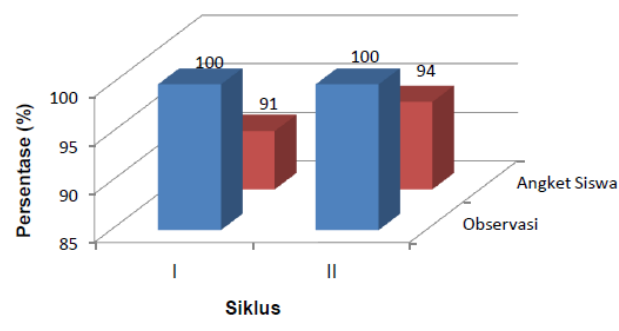

Gambar 3. Grafik Pencapaian Indikator Interaksi Guru dengan Siswa dan Siswa dengan Siswa padaSiklus I dan II dari Hasil Observasi dan Angket Siswa. Dari hasil observasi (biru), pencapaian indikator interaksi guru dengan siswa dan siswa dengan siswa pada siklus I dan II adalah $100 \%$. Dari hasil angket siswa (merah), indikator interaksi guru dengan siswa dan siswa dengan siswa meningkat dari 91\% pada siklus I menjadi 94\% pada siklus II.

indikator, diantaranya siswa bertanya bila tidak memahami materi pelajaran dan siswa terlibat dalam pemecahan masalah. Siswa dapat bertanya kepada guru atau kepada siswa lain apabila ada materi pelajaran yang belum dipahami. Dari catatan lapangan, siswa lebih banyak bertanya kepada siswa lain dibandingkan kepada guru. Keterlibatan siswa dalam pemecahan masalah dilihat dari diskusi kelompok dan diskusi kelas. Dari hasil observasi, diketahui bahwa keaktifan siswa dalam proses pembelajaran masih kurang (<70\%). Berdasarkan catatan lapangan, hanya sekitar 7 siswa (dari total 35 siswa) yang berani bertanya kepada guru apabila ada materi pelajaran yang belum dipahami. Keterlibatan siswa dalam pemecahan masalah juga belum banyak $(48,60 \%)$. Banyak siswa belum terlibat secara aktif untuk memecahkan masalah baik dalam kelompok maupun dalam kelas.

c. Interaksi Guru dengan Siswa dan Siswa dengan Siswa

Adanya interaksi antara guru dengan siswa dan siswa dengan siswa dilihat dari beberapa sub indikator yaitu adanya tanya jawab, baik antara guru dengan siswa maupun siswa dengan siswa, dan guru sebagai fasilitator. Guru sebagai fasilitator dapat dilihat dari guru melengkapi jawaban siswa, memberikan kesempatan kepada siswa untuk bertanya dan menanggapi pendapat atau pertanyaan siswa lain, serta mengontrol setiap siswa selama kegiatan pembelajaran. selama proses pembelajaran, terdapat tanya jawab baik antara guru dengan siswa maupun antara siswa dengan siswa lain. Hal tersebut didukung juga dari hasil catatan lapangan. Selain itu, guru juga bertindak sebagai fasilitator selama kegiatan pembelajaran. Hal ini menunjukkan bahwa indikator interaksi antara guru dengan siswa dan siswa dengan siswa telah tercapai dengan baik (>70\%).

\section{d. Kemampuan dan Keterampilan Guru \\ Indikator kemampuan dan keterampilan} guru terdiri dari sub indikator guru menguasai materi pelajaran, terampil menggunakan media pembelajaran, dan mampu mengendalikan kegiatan siswa. Penguasaan materi pelajaran oleh guru dapat dilihat dari kemampuan guru dalam menjelaskan materi dan kemampuan guru dalam menjawab pertanyaan siswa. Keterampilan guru dalam menggunakan media pembelajaran dilihat dari kemampuan guru mengoperasikan laptop dan LCD proyektor. Berdasarkan hasil observasi, $100 \%$ observer menyatakan bahwa penguasaan materi pelajaran oleh guru sudah sangat baik. Selain itu, guru juga terampil menggunakan media pembelajaran dan mampu mengendalikan kegiatan siswa dengan baik. Hal tersebut didukung oleh hasil angket siswa yaitu sebanyak $97 \%$ menyatakan bahwa guru menguasai materi pelajaran dan $91 \%$ siswa menyatakan bahwa guru terampil menggunakan media pembelajaran. Hal ini menunjukkan bahwa indikator kemampuan dan keterampilan guru telah tercapai dengan baik (>70\%). 


\section{e. Kualitas Hasil Belajar Siswa}

Indikator terakhir yang diamati adalah kualitas hasil belajar siswa yang diperoleh siswa dari hasil tes akhir siklus. Pada evaluasi akhir siklus I, rerata hasil belajar siswa adalah 73,89. Jumlah siswa yang mendapatkan nilai kurang dari 75 (belum mencapai KKM) sebanyak 12 orang. Hal tersebut mengindikasikan bahwa kualitas hasil belajar siswa pada siklus I masih kurang baik.

Berdasarkan pembahasan di atas, dapat diketahui bahwa belum semua indikator efektivitas pembelajaran pada siklus I tercapai dengan baik. Hal ini dapat disebabkan oleh antara lain :

a. Siswa yang memanfaatkan text book (buku pelajaran) dan LKS praktikum sebagai referensi belajar selama proses pembelajaran di kelas masih kurang (47,15\%).

b. Masih banyak siswa $(69,30 \%)$ yang kurang aktif dalam diskusi, baik diskusi kelompok maupun diskusi kelas.

Untuk mengatasi kendala-kendala yang ditemui pada siklus I, dilakukan beberapa perubahan pada siklus II, diantaranya :

a. Guru menugaskan siswa untuk membawa text book (buku pelajaran) setiap proses pembelajaran.

b. Pembelajaran melalui diskusi antar kelompok

c. Pembentukan kelompok baru yang terdiri dari siswa yang aktif dan yang kurang aktif lebih merata sehingga keaktifan siswa dapat meningkat.

\section{Siklus II}

Siklus II terdiri dari dua pertemuan. Pada pertemuan pertama dilakukan pembelajaran Larutan Penyangga melalui kegiatan praktikum di laboratorium menggunakan panduan berupa LKS dan CD praktikum. Pertemuan kedua adalah tes tertulis.
Seperti pada pertemuan pertama pada siklus I, pertemuan pertama siklus II diawali dengan pembelajaran di kelas. Guru mengingatkan kembali kepada siswa mengenai materi larutan penyangga yang telah dipelajari pada siklus I. Kemudian, guru membagikan LKS praktikum kepada masingmasing siswa dan menayangkan video praktikum yang akan dilakukan, yaitu mengenai larutan penyangga dalam produk minuman komersial. Siswa mengamati dan menyimak dengan baik untuk mendapatkan gambaran mengenai praktikum yang akan mereka lakukan.

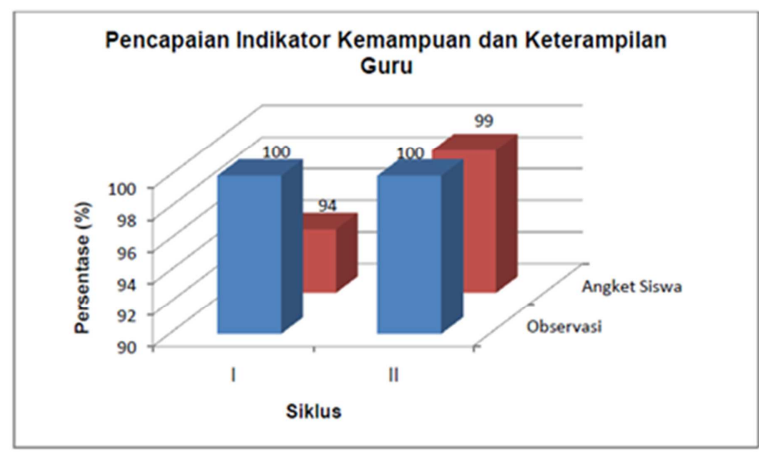

Gambar 4. Grafik Pencapaian Indikator Kemampuan dan Keterampilan Guru pada Siklus I dan Ildari Hasil Observasi dan Angket Siswa. Dari hasil observasi (biru), pencapaian indikator kemampuan dan keterampilan guru pada siklus I dan II adalah 100\%. Dari hasil angket siswa (merah), indikator kemampuan dan keterampilan guru meningkat dari $94 \%$ pada siklus I menjadi $99 \%$ pada siklus II.

Sebelum ke laboratorium, guru membagi siswa menjadi delapan kelompok baru (berbeda dengan kelompok pada siklus I) yang terdiri dari 4-5 orang. Selanjutnya, seluruh siswa menuju laboratorium untuk melakukan kegiatan praktikum sesuai instruksi yang diberikan oleh guru. Secara umum, hasil pengamatan indikator-indikator efektivitas adalah sebagai berikut :

a. Keterlaksanaan Program Pembelajaran oleh Siswa

Dari tabel di atas, dapat dilihat bahwa pemanfaatan sumber belajar, oleh siswa 
masih sangat kurang $(47,15 \%)$ meskipun dari hasil angket siswa ada peningkatan dari siklus I (63,50\% menjadi 65\%). Berdasarkan hasil catatan lapangan, sudah ada beberapa siswa (5 orang) yang membawa buku pelajaran, tetapi belum dimanfaatkan secara maksimal. Hal ini kemungkinan disebabkan guru kurang tegas dalam menugaskan siswa untuk selalu membawa buku pelajaran ketika proses pembelajaran kimia. Secara keseluruhan, indikator keterlaksanaan program pembelajaran oleh siswa pada siklus II telah tercapai dengan baik. Grafik perbandingan pencapaian indikator keterlaksanaan program pembelajaran oleh siswa pada siklus I dan II dapat dilihat pada Gambar 1.

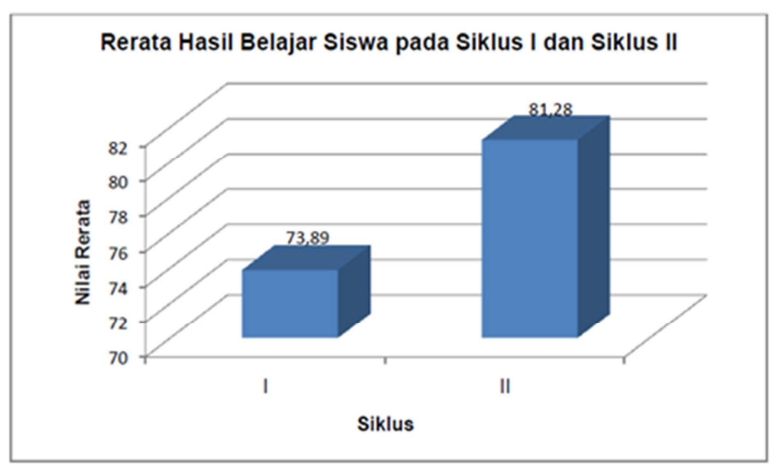

Gambar 5. Grafik Perbandingan Rerata Hasil Belajar Siswa pada Siklus I dan II. Pada siklus I, rerata hasil belajar siswa adalah 73,89. Pada siklus II, rerata hasil belajar siswa mengalami peningkatan yaitu menjadi 81,28.

\section{b. Keaktifan Siswa dalam Proses Pembelajaran \\ Indikator keaktifan siswa dalam proses} pembelajaran pada siklus II mengalami peningkatan dibandingkan siklus I. Hal ini terlihat pada meningkatnya jumlah siswa yang bertanya apabila tidak memahami materi pelajaran, yaitu dari $31,30 \%$ pada siklus I menjadi $51,40 \%$ pada siklus II. Selain itu, keterlibatan siswa dalam pemecahan masalah juga terlihat meningkat, yaitu dari $48,6 \%$ pada siklus I menjadi 69,3\% pada siklus II. Meskipun mengalami peningkatan, indikator keaktifan siswa dalam proses pembelajaran pada siklus
II belum tercapai dengan baik ( $<70 \%)$. Grafik perbandingan pencapaian indikator keaktifan siswa dalam proses pembelajaran pada siklus I dan II dapat dilihat pada Gambar 2.

\section{c. Interaksi Guru dengan Siswa dan Siswa dengan Siswa}

Selama proses pembelajaran pada siklus II, terdapat tanya jawab antara guru dengan siswa dengan frekuensi yang lebih banyak dibandingkan pada siklus I. Hal tersebut didukung oleh hasil angket siswa, yaitu sebanyak 91\% siswa menyatakan adanya tanya jawab antara guru dengan siswa. Hasil tersebut meningkat bila dibandingkan hasil angket siswa pada siklus I yang hanya $88 \%$. Selain antara guru dengan siswa, tanya jawab juga terjadi antara siswa dengan siswa selama proses pembelajaran, sedangkan guru hanya bertindak sebagai fasilitator. Secara keseluruhan, indikator interaksi antara guru dengan siswa dan siswa dengan siswa pada siklus II telah tercapai dengan baik (>70\%). Grafik perbandingan pencapaian indikator interaksi guru dengan siswa dan siswa dengan siswa pada siklus I dan II dapat dilihat pada Gambar 3.

\section{d. Kemampuan dan Keterampilan Guru}

Berdasarkan hasil pengamatan, penguasaan materi pelajaran oleh guru dan keterampilan guru menggunakan media pembelajaran jauh lebih baik dari sebelumnya. Hal ini didukung oleh hasil angket siswa, yaitu $100 \%$ siswa menyatakan guru menguasai materi pelajaran (meningkat dibanding pada siklus I yang hanya $97 \%$ ) dan sebanyak $98 \%$ siswa menyatakan guru terampil menggunakan media pembelajaran (meningkat dibanding pada siklus I yang hanya 91\%).

Selain itu, guru juga mampu mengendalikan kegiatan siswa dengan baik. Secara keseluruhan indikator kemampuan dan keterampilan guru pada siklus II telah tercapai dengan baik (>70\%). Grafik perbandingan 
pencapaian indikator kemampuan dan keterampilan guru dapat dilihat pada Gambar 4.

e. Kualitas Hasil Belajar Siswa

Pada evaluasi akhir siklus II, rerata hasil belajar siswa mengalami peningkatan dibandingkan pada siklus I, yakni 81,28. Jumlah siswa yang mendapatkan nilai kurang dari 75 (KKM) juga jauh lebih sedikit dibandingkan siklus I, yaitu sebanyak 5 orang. $\mathrm{Hal}$ tersebut mengindikasikan bahwa kualitas hasil belajar siswa pada siklus II jauh lebih baik dibanding siklus I. Grafik perbandingan rerata hasil belajar siswa pada siklus I dan II dapat dilihat pada Gambar 5.

Dari pembahasan di atas, dapat diketahui bahwa semua indikator efektivitas pembelajaran telah tercapai dengan baik dan mengalami peningkatan dari siklus I ke siklus II. Secara umum, persentase pencapaian indikator efektivitas pembelajaran pada siklus I dan II disajikan dalam Tabel 1.

\section{Kesimpulan dan Saran \\ Kesimpulan}

Berdasarkan hasil penelitian, dapat disimpulkan bahwa penggunaan pendekatan SAVI dan panduan dan praktikum dapat meningkatkan efektivitas pembelajaran Larutan Penyangga pada siswa kelas XI IPA 3 SMAN 21 Jakarta. Untuk dapat meningkatkan efektivitas pembelajaran Larutan Penyangga melalui pendekatan SAVI menggunakan panduan praktikum berbasis ICT, terlebih dahulu perlu diketahui gaya belajar dominan siswa dan karakteristik materi yang diajarkan. Setelah itu, guru dapat menentukan metode dan media pembelajaran yang sesuai dengan karakteristik materi dan gaya belajar dominan siswa. Penggunaan panduan dan CD praktikum sebagai implementasi dari pendekatan SAVI dapat mengoptimalkan gaya belajar visual dan auditori siswa. Selain itu, kegiatan praktikum di laboratorium yang sesuai dengan karakteristik materi Larutan Penyangga dapat mengoptimalkan gaya belajar somatis siswa.

\section{Saran}

Berdasarkan kegiatan penelitian yang telah dilakukan, maka disarankan kepada :

1. Para guru untuk menerapkan pendekatan SAVI (Somatis, Auditori, Visual, dan Intelektual) dalam proses pembelajaran pada materi lain.

2. Para guru untuk menggunakan panduan praktikum berbasis ICT pada materi lain yang membutuhkan kegiatan praktikum di laboratorium.

3. Para guru dan peneliti agar lebih kreatif dan inovatif dalam mengembangkan media pembelajaran.

4. Para peneliti yang ingin melakukan penelitian mengenai efektivitas pembelajaran agar menggunakan skala Likert pada lembar observasi untuk mengamati indikator kemampuan dan keterampilan guru serta interaksi antara guru dengan siswa dan siswa dengan siswa sehingga hasil yang diperoleh lebih objektif dan terperinci.

\section{Penghargaan}

Peneliti mengucapkan terima kasih kepada Jurusan Kimia, Fakultas Matematika dan Ilmu Pengetahuan, Universitas Negeri Jakarta serta SMA Negeri 21 Jakarta yang telah membantu dalam melaksanakan penelitian ini

\section{Daftar Pustaka}

[1] Anonim. 2008. Panduan Penyelenggaraan Rintisan Sekolah Menengah Atas Bertaraf Internasional (RSMA-BI). Jakarta : Depdiknas. 
[2] Anonim. 2007. Pedoman Penjaminan Mutu Sekolah/Madrasah Bertaraf Internasional pada Jenjang Pendidikan Dasar dan Menengah. Jakarta : Depdiknas.

[3] Meier, D. 2005. The Accelerated Learning Handbook. New York : McGraw-Hill.

[4] Arikunto, S., Suhardjono, dan Supardi. 2009. Penelitian Tindakan Kelas. Jakarta : Bumi Aksara.

[5] Mutiara, E. 2011. Pengembangan LKS dan CD Pendukung Praktikum Bilingual Berbasis ICT pada Materi Larutan Penyangga di Kelas XI Rintisan Sekolah Menengah Atas Bertaraf Internasional. Jakarta : Universitas Negeri Jakarta. 